\title{
New panel set to beat biotech's bad image...
}

Munich

Public concern over the social impact of the life sciences has prompted the European Commission to set up a panel of 11 prominent biologists to advise it on the scientific aspects of social controversies about bioscience and biotechnology.

The 'Biosciences High Level Group' (BHLG), announced last week, has been established by research commissioner Philippe Busquin to complement the commission's existing advisory group on bioethics.

The move aims to establish direct contacts between life scientists and European decision-makers on a more regular basis. The lack of active lobbying by scientists compared with big companies and pressure groups - is seen by some as an important reason for their relatively small influence in the European Commission's policies (see Nature 398, 646; 1999).

The BHLG will also campaign for more effective industrial exploitation of new biotechnological tools in areas such as safe food production, decomposition of harmful substances, and the preservation of biodiversity. At the same time, it will suggest how new public controversies around the life sciences might be avoided by improved information and education.

The panel features scientists from nine European countries, including biochemist Sir Tom Blundell, the former chief executive of the UK Biotechnology and Biological Sciences Research Council, Nobel laureate Rolf Zinkernagel, of the University of Zurich, and the eminent German geneticist ErnstLudwig Winnacker.

The group's members have been chosen for both their scientific standing and their ability to communicate with lay people. Winnacker, for example, has long worked for the public understanding of genetics in Germany, and Zinkernagel campaigned against proposed restrictions on the use of genetic engineering techniques in Switzerland (see Nature 388, 315; 1997).

Axel Kahn, a geneticist at the Institut Cochin in Paris, will chair the panel. According to Kahn, the group's primary goal is to suggest ways of bridging the widening gap between the scientific and commercial opportunities presented by the biosciences and European citizens' concerns about issues such as genetically modified food, genetic screening, biomedicine and the patenting of biotechnological inventions.

Indeed, the preliminary results of a 'Eurobarometer' opinion poll on biotechnology, published last week, suggest continuing insecurity and ignorance about these issues (see right). The public's trust in political expertise also seems to be in decline.

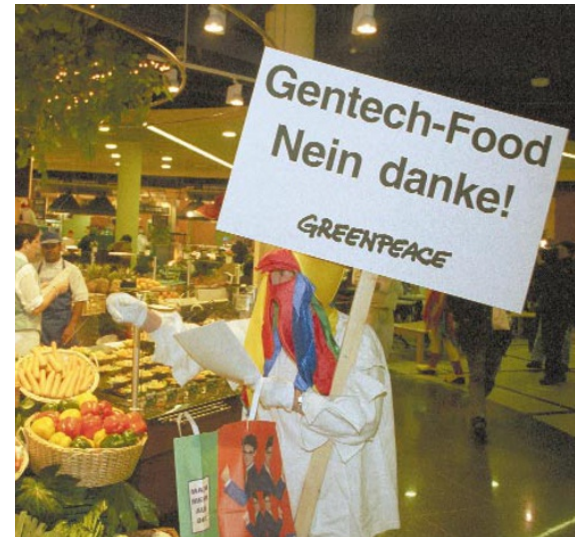

Public distrust: rebuilding confidence in biotechnology needs help from scientists.

"I want to ask scientists to return to the debating table, as Europe needs to make sure that it has a sound basis for discussing these issues," Busquin said after the advisory groups inaugural meeting last week. He added that a "conscious political decision" relating to the biosciences is not possible without informed advice and public debate.

The group is not linked to the commission's Framework programmes on research, nor is it supposed to make direct funding recommendations. Rather it will act as a think-tank, developing measures for reconciling the interests of the public, industry and basic researchers in Europe. The practical details of how the group will approach

these goals are yet to be worked out.

The BHLG's first task will be to advise the commission on the topics and purposes of a summit on the biosciences, planned to take place in Brussels in November. The meeting will give the major European stakeholders in biotechnology, including the public, a platform for their views.

"Many Europeans believe that scientists are trying to force things on society which people neither want nor need," says BHLG member Marc Van Montagu, a plant geneticist at the University of Ghent and founder of the Ghent-based company Plant Genetic Systems.

"If the next generation of Europeans is to be more confident in biotechnology, we need to show that research in the life sciences is not being carried out just for the benefit of a handful of companies, scientists and brokers, but that it serves the whole community."

In contrast to other European research advisory bodies, such as the former European Science and Technology Assembly, which tend to include both academic and industrial researchers, the new group will take a purely science-based perspective.

According to Van Montagu, this will help it meet its goals. "The European Commission is often perceived by the public as being industry-biased," he says. "This has somewhat tarnished the image of commission-funded research, particularly in the life sciences".

Quirin Schiermeier

\section{... as European public remains sceptical}

Paris

Public scepticism in Europe towards biotechnology has increased in Europe over the past three years. But at the same time, public confidence in all sources of information about biotechnology — including both environmentalist and academic groups - has fallen, according to an opinion survey published last week.

The poll, taken last year as part of the regular Eurobarometer exercise funded by the European Commission, surveyed 16,000 people in the 15 member states of the European Union. It assessed their attitudes towards new developments such as information technology, telecommunications, space exploration and new materials.

While the approval levels of these categories have stayed stable since the previous poll three years ago, biotechnology suffered a significant drop: 41 per cent of those polled said that biotechnology would improve the quality of life in the next 20 years, compared with 47 per cent in 1997. Only nuclear technology ranked lower on the confidence scale, with 26 per cent support.

Some researchers, however, were surprised that the drop in confidence was not greater. "Considering the scale of the debate on GMOs, we were expecting Europeans to show even more distrust now than three years ago," says Daniel Boy, director of research at the Centre d'étude de la vie politique française, one of the groups in the study.

Opinions vary widely on the applications of biotechnology. Most of those polled favoured genetic screening for inherited diseases, the use of GM organisms to clean up pollution, and of genetic engineering to develop medicines and vaccines. But the production of GM foods, cloning human cells or tissue to treat patients, and cloning animals for medical applications received much less support.

One of the most marked changes since 1997, according to the poll, is the drop in public trust in professional organizations. Only 17 per cent see international institutions as reliable sources of information, and just 15 per cent view national public authorities as dependable.

Eurobarometer also found that respondents feel inadequately informed about biotechnology 81 per cent feel uninformed on these issues. Heather McCabe 